Hasanli B.N.

DOI: 10.25108/2304-1730-1749.iolr.2020.62.78-86

UDC 364.29

\title{
The concept of violence and its types
}

\begin{abstract}
As we know, the importance of the problem of child abuse is recognized by both the state and society. For example, the existence of a system of state and non-governmental social services that protect children, as well as charities that support families and children, once again proves that this problem is always in the spotlight. The article also addresses the psychological, social, and economic aspects of violence. In addition, the article describes the types of violence that have developed in recent years.

One of the important issues mentioned in the article is the translation and use of certain terms. As we know, the vast majority of theoretical provisions in local science are based on the scientific research of foreign scientists. There are many shortcomings in the translation process of certain categories from Russian to Russian. In many countries, the importance of the problem of child abuse is recognized by both the state and society as a whole. This is evidenced by the existence of a system of state and non-governmental social services that protect the rights of children, charities that support families and children. In addition, this problem is increasingly becoming the focus of international and regional conferences. The problem of child abuse and neglect abroad is related to the child's willingness to protect, in practice, the physical and psychological abuse, abuse or neglect.

Child abuse is prevalent in all countries of the world. What is violence? What causes problems and why do children suffer the most? Researchers have been very interested in this problem and have conducted research. Their conclusion is that the emergence of this problem is related to the early 21 st century. This century has been remembered for its mischief in the memories. After all, wars, crimes of humanity, terrorism, self-indulgence, the spread of indifference among people, and so on, have led to this. We can safely say that one of the key features of the 21 st century is the victory of the evil and the coming of power through violence against the weak. Term-like violence is the use of various coercive actions on a child around the world. The study of child abuse in the family as an independent and significant issue is the first step towards addressing it and minimizing its consequences. The article also emphasizes the need to establish a system of public control over the observance of children's rights in the country, to prevent the use of such institutions in the process, based on the example of several foreign countries.
\end{abstract}

Keywords: violence; abuse; abuse; child rights; society.

\section{References}

1. Infantil'nyi sindrom. Jurnal Amerikansoyi meditsinskoyi assotsiatsii [Infantile syndrome. Journal of American Medical Association]. Available at: https://cont.ws/@sari/843393 (accessed 12.02.2020).

\footnotetext{
•Hasanli Bahar Nazim - Azerbaijan University, II year master student, Azerbaijan. E-mail: 1994.bh@mail.ru
} 
2. Hartman S. O domashnem nasilii v SSHA [On home violence in the USA]. Moscow, 1993, $257 \mathrm{p}$.

3. Safonova T. Nasilie nad det'mi: priroda, prichiny, sotsial'naya $i$ pravovaya zaschita [Violence over children: nature, reasons, social and legal protection]. Moscow, 1993, 27 p.

4. Nasilie $v$ otnoshenii deteyi $i$ roditel'skaya psikhopatologiya [Violence over children and relative psychopathology]. Konferentsiya Nasilie i zaschita deteyi v mire [Conference Violence and protection of children]. Moscow, 1-3 October 2017, $369 \mathrm{p}$.

5. Nasilie i ego vliyanie na zdorov'ye. Doklad VOZ o situatsii v mire. 2003 [Violence and its impact on health. Report of World Health Organization. 2003]. Available at: https://apps.who.int/iris/bitstream/handle/10665/42495/5777702252_rus.pdf;jsessionid= DAFD DB7D3152DD8D88D94F15F0018166? sequence=4 (accessed 14.02.2020) 


\section{Həsənli B. N.}

DOI: $10.25108 / 2304-1730-1749$.iolr.2020.62.78-86

UOT 364.29

\section{Zorakılıq anlayışı və onun növləri}

Xülasə: Bildiyimiz kimi, uşaq zorakılıq probleminin əhəmiyyəti həm dövlət, həm də cəmiyyət tərəfindən tanınır. Məsələn, uşaqları qoruyan həm dövlət, həm də qeyri-dövlət sosial xidmətlərin sisteminin, habelə ailələrə və uşaqlara yardım göstərən xeyriyyə təşkilatların olması bir daha göstərir ki, bu problem daim diqqət mərkəzindədir. Məqalədə həmçinin zorakılı̆̆ın psixoloji, sosial və iqtisadi aspektlərinə də nəzər salınıb. Bundan başqa, məqalədə son illərdə zorakılığın formalaşan növləri də öz əksini tapıb.

Məqalədə əksini tapmış vacib məsələlərdən biri də bəzi terminlərin tərcüməsi və mətnlərdə istifadəsi ilə bağlıdır. Bildiyimiz kimi, yerli elmdəki nəzəri müddəaların böyük əksəriyyəti xarici alimlərin elmi araşdırılmalarına söykənmişdir. Müəyyən kateqoriyaların xarici dildən tərcüməsi prosesində bir çox çatışmamazlıqlara rast gəlinir.Bir çox ölkələrdə uşaq zorakılı̆̆ı probleminin əhəmiyyəti həm dövlət, həm də bütövlükdə cəmiyyət tərəfindən tanınır. Bu, uşaqların hüquqlarını qoruyan dövlət və qeyri-dövlət sosial xidmətləri sisteminin, ailələrə və uşaqlara yardım göstərən xeyriyyə təşkilatlarının olması ilə sübut olunur. Bundan əlavə, bu problem getdikcə beynəlxalq və regional konfransların mərkəzi mövzusuna çevrilir. Xaricdə uşaqlara qarşı zorakılıq və laqeydlik problemi praktikada uşağın fiziki və psixoloji zorakılıqdan, istismardan və ya laqeyd qalmaqdan, qorunma hüququnu təmin etmək istəyi ilə bağlıdır.

Açar sözlər: zorakılıq; istismar; sui-istifadə; uşaq hüquqları; cəmiyyət.

Uşaq zorakılığı dünyanın bütün ölkələrində çoxluq təşkil edir. Zorakılıq nədir? Nə kimi problemlər yaradır və niyə zorakılığa ən çox uşaqlar məruz qalır? Tədqiqatçılar bu problemlə yaxından maraqlanıb, araşdırmalar aparıblar. Onların gəldiyi nəticə ondan ibarətdir ki, bu problemin daha qabarıq üzə çıxması XXI əsrin əvvəlləri ilə bağlıdır. Bu əsr yaddaşlarda öz eybəcərlikləri ilə yadda qalan oldu. Ax1 bu əsrdə müharibələr, bəşəri cinayətlər, terrorlar, özünəqəsdlər, insanlar arasında biganəlik keyfiyyətinin yayılması və s.baş vermişdir. Ominliklə deyə bilərik ki, XXI əsrin əsas xüsusiyyətlərindən biri şərin xeyir üzərində qələbəsi, güclünün zəif üzərində zorakılıq vasitəsilə hakimiyyətə gəlməkdir. Termin kimi zorakılıq bütün dünyada uşağa müxtəlif məcburetmə hərəkətlərin tətbiqidir. Ailədə uşaq zorakılığının müstəqil və əhəmiyyətli bir problem kimi öyrənilməsi, bunun həllinə və nəticələrinin minimuma endirilməsinə yönəlmiş ilk addımdır. Məqalədə ölkədə uşaq hüquqlarına riayət olunmasına ictimai nəzarət sisteminin yaradılması, bir neçə xarici ölkələrin nümunəsinə əsaslanaraq uşaqlara qarşı qəddarlıq hallarının qarşısının alınması və bu prosesdə belə institutların tətbiqinin vacibliyi də vurğulanmışdır.

Hal-hazırda dünyada əsas qlobal problemlərdən biri uşaqlara qarşı zorakılıqdır. Zorakılıq nədir? Nə kimi problemlər yaradır və niyə zorakılığa ən çox uşaqlar məruz qalır? Tədqiqatçılar bu

\footnotetext{
•Həsənli Bahar Nazim qızı - Azərbaycan Universitetinin II kurs magistr tələbəsi, Azərbaycan. E-mail: 1994.bh@mail.ru
} 
problemlə yaxından maraqlanıb, araşdırmalar aparıblar. Onların gəldiyi nəticə ondan ibarətdir ki, bu problemin daha qabarıq üzə çıxması XXI əsrin əvvəlləri ilə bağlıdır.

$\mathrm{Bu}$ əsr yaddaşlarda öz eybəcərlikləri ilə yadda qalan oldu. Axı bu əsrdə müharibələr, bəşəri cinayətlər, terrorlar, özünəqəsdlər, insanlar arasında biganəlik hallarının yayılması və s.baş vermişdir. Ominliklə deyə bilərik ki, XXI əsrin əsas xüsusiyyətlərindən biri şərin xeyir üzərində qələbəsi, güclünün zəif üzərində zorakılıq vasitəsilə hakimiyyətə gəlməsidir. Termin kimi zorakılıq bütün dünyada uşağa müxtəlif məcburetmə hərəkətlərinin tətbiqidir [1, s. 24].

Bir çox ölkələrdə uşaq zorakılığg probleminin əhəmiyyəti həm dövlət, həm də bütövlükdə cəmiyyət tərəfindən tanınır. Bu, uşaqların hüquqlarını qoruyan dövlət və qeyri-dövlət sosial xidmətləri sisteminin, ailələrə və uşaqlara yardım göstərən xeyriyyə təşkilatlarının olması ilə sübut olunur. Bundan əlavə, bu problem getdikcə beynəlxalq və regional konfransların mərkəzi mövzusuna çevrilir.

Müxtəlif dünya ölkələrində uşaqlara qarşı zorakılıq və laqeydlik problemi praktikada uşağın fiziki və psixoloji zorakılıqdan, istismardan və ya laqeyd qalmaqdan qorunma hüququnu təmin etmək istəyi ilə bağlıdır.

Uşaq zorakılığı ilə mübarizə etmək məqsədilə, Azərbaycan BMT-nin Uşaq hüquqları haqqında Konvensiyasına və bu Konvensiyanın Olavə fakültativ Protokollarına qoşulmuşdur. Bundan başqa, coxlu sayda Dövlət Proqramları, Tədbirlər planları həyata keçirilməkdədir.

Bu Proqramların əhəmiyyəti, heç şübhəsiz, çox böyükdür. Çünki, bu sənədlər uşaqların fiziki, əqli, əxlaqi inkişafina yönəldilmişdir.

Zorakılığın psixoloji, sosial və iqtisadi aspektləri mövcuddur [4, s.75]. Bundan başqa, son dövrlərdə zorakılığın növləri də formalaşıb:

1. Fiziki zorak1lıq;

2. İqtisadi zorak1lıq;

3. Psixoloji zorakılıq (mənəvi zorakılıq);

4. Cinsi zorakiliq.

Fiziki zorakılıq - uşaqlara fiziki cəhətdən zərər dəyməsidir. Bura vurmalar, döymələr, sillələmələr, hətta təpikləmələr aiddir və bu bədəndə müxtəlif izlər qoyur, xəsarətlərə gətirib çıxarır.

Fiziki zorakılığın ən çox yayılmış sübutu qançırlar, həmçinin dişləmələr, yanıqlar və sümük qırıqlarıdır. Uşaqda yuxarıda göstərilən zərərin səbəblərini müəyyən edərkən, uşağın görünüşünə və davranışına diqqət yetirmək lazımdır, çünki fiziki zorakılıq tez-tez uşağın əsas ehtiyaclarına laqeyd qaldıqda baş verir.

Etinasılıq nəticəsində meydana gələn zorakılıqda uşaq baxımsız, gigiyenik cəhətdən laqeyd, bədənində yaralar olan, susuzluqdan əziyyət çəkə bilər. Boy və çəkidə bir gerilik fiziki cəzanın tətbiq olunacağını da göstərə bilər.

Psixoloji (emosional) qəddar davranış birdəfəlik və ya xroniki zehni təsir, düşmən və ya laqeyd münasibət, həmçinin uşağın özünə hörmət etməməsinə səbəb olan, şəxsiyyət inkişafına mane olan və patoloji xarakter əlamətlərinin formalaşmasına səbəb olan digər davranış kimi başa düşülür. Psixoloji istismarın özəlliyi ondadır ki, bu forma məişət zorakılığının bütün növlərini müşayiət edir, onların tərkib hissəsini təşkil edir.Yerli mütəxəssislərin əksəriyyətinin tərifinə görə, cinsi istismar - kiçik və ya yeniyetməlik yaşında uşağın bu və ya digər səbəblərə görə bir şəxsin onunla cinsi əlaqədə olmasi, bir sıra mənfəətlərə nail olmaq məqsədini daşıyır.

Müxtəlif araşdırmalara görə, yaşından, zehni sağlamlığından və ailədəki vəziyyətindən asılı olmayaraq hər hansı bir uşaq cinsi təcavüzün qurbanı ola bilər. Zorakılıq zamanı uşaqların təxminən 
60\%-i 11 yaşınadək, 40\%-i isə yeniyetmələr olur və mütəxəssislərin fikrincə, bunlar ümumiyyətlə əqli qüsurlu yeniyetmələrdir [3, s. 42].

Uşaq zorakılığının xüsusi formalarından biri onların əsas ehtiyaclarına etinasızlıqdır. Bu da "uşaqlara ibtidai qayğı tərbiyəsi üçün cavabdeh olan valideynlərin, qəyyumların və ya digər yetkinlərin olmaması, onların emosional vəziyyətinin pozulması və təhdid olunması" kimi müəyyən edilir.

Uşağın əsas ehtiyaclarına laqeyd yanaşmanın özəlliyi, ilk növbədə, yalnız xarici sosialiqtisadi amillərlə müəyyənləşdirilir və daha sonra isə, valideynlərin səhlənkarlığ 1 və ya cinayətkar hərəkəti ilə ifadə olunur. Sonuncu yalnız uşaq istismarının bu forması üçün xarakterikdir və buna görə də "uşaq zorakılığı" ümumi anlayışının əhatəsini genişləndirir.Bununla birlikdə, təcrübə göstərir ki, uşağın əsas ehtiyaclarına laqeyd yanaşma zorakılığı sübuta yetirən faktların üzə çıxarılmasını çətinləşdirir. Məsələn, bir uşağın evdə uzun müddət tək qalması özü də zorakılıq əlamətidir [5, s. 49].

Bəzi hallarda ədəbiyyatda laqeydliyin də növlərindən bəhz olunur: fiziki və mənəvi laqeydlik.Bu növlərə əlavə olaraq, xarici mənbələr intellektual və sosial laqeydliyi də əlavə edirlər. Fikrimizcə, uşaqlara qarşı hər hansı hərəkəti zorakılıq adlandırmaq çətindir, çünki bu laqeydlik formaları onun fiziki və ya psixi sağlamlığı üçün ciddi problemlər yarada bilər.

Mənəvi zorakılıq o deməkdir ki, uşaq mənən zərər çəkir. Bu hall o vaxt yaranır ki, uşağın mənəvi dünyasını dağıtmağa nail olurlar.

Psixoloji zorakılıq - Psixoloji zorakılıq və ya mənəvi zorakılı̆̆a hədələmə, verbal təhqir, gözlə və jestlə təzyiq, şantaj, cinsi zorakılıq və s. aiddir. Biz zorakılıq deyəndə təkcə fiziki mənada başa düşsək də, insana ən böyük travma verən və uzunmüddətli təsir, iz qoyan məhz psixoloji zorakıliqdir.

İqtisadi zorakılıq - uşaqların maddi imkanlarına zərər vururlar.

Cinsi zorakılıq - uşağın razılı̆̆ı olmadan onu cinsi münasibətlərə məcbur edirlər.

Bütün bu zorakılıq növlərinin baş verməsinin bir səbəbi var - uşaq öz hüquqlarını bilmir və biləndə də, öz hüquqlarına laqeyd münasibət göstərir.

Digər tərəfdən, zorakılıq və xüsusən məişət zorakılı̆̆ı, çox sayda fənlərin elmi tədqiqat mövzusudur. Beləliklə, elmi yenilikdir, problemin çoxölçülüyü, əsas anlayışlarının müxtəlif tədqiqat sahələrinin mütəxəssisləri, həm nəzəriyyəçilər, həm də praktikantlar tərəfindən elmi ədəbiyyatında konseptual qarışıqlıq və iş yükü yaratması ilə əlaqələndirilməməsidir.

Ailədəki uşaq istismarı problemindəki terminoloji qarışıqlı̆̆ın digər bir səbəbi, yerli elmdəki nəzəri müddəaların və praktik inkişafların böyük əksəriyyətinin xarici alimlərin elmi araşdırmalarına söykənməsidir. Yəni, xarici elmi tədqiqatların yerli elmin ehtiyaclarına uyğunlaşdırılmasında aşkar çatışmazlıqlar var.

Hər şeydən əvvəl burada müəyyən anlayışların və kateqoriyaların digər dildən rus dilinə tərcüməsi prosesində əhəmiyyətli bir maneə yaranır. Məsələn, ingilis dilində "sui-istifadə" anlayışının bir çox mənası var: təhqir, pis rəftar və s. Bunların hər biri müstəqil bir termin kimi rus dilində istifadə olunur və birini sərbəst şəkildə digəri ilə əvəz etmək olar və ya əksinə.

Yerli ədəbiyyatın təhlilinə görə, ailədəki uşaq istismarı probleminin konseptual baxışına iki əsas anlayış daxildir: "zorakılıq" və "sui-istifadə”. Bundan əlavə, ədəbiyyatda "pis rəftar" anlayışına rast gəlmək olar, lakin biz bu problem çərçivəsində istifadə zərurətini şübhə altına alırıq. Fikrimcə, onların elmi mətnlərdə istifadəsi düzgün deyil, çünki eyni hadisəni xarakterizə edərək problemin başa düşülməsinə əlavə məna verir. 
Ailə, Qadın və Uşaq Problemləri üzrə Dövlət Komitəsinin araşdırmalarına əsasən, başqa uşaqlarla müqayisədə yoxsul və uğursuz ailələrdən olan uşaqların davranışındakı pozuntular 3 dəfə çox, xroniki xəstəliklərə tutulma halları 2 dəfə çox, məktəb problemləri, emosional pozuntular, hiperaktivlik 2 dəfə çoxdur. Bundan başqa, rifah vəziyyətinin aşağı olması uşaq mühitindəki zorakılıq hallarının artmasını şərtləndirir [4, s. 73].

Belə ki, zorakılıq halları qızlar arasında 3 dəfə çox, oğlanlar arasında 5 dəfə çoxdur. Fikrimizcə, bu göstəriciləri yalnız iqtisadi mərhumiyyətlərlə izah etmək düzgün olmazdı. Belə ki, ağır iqtisadi şəraitdə yaşayan bir çox uşaqlar məktəbdə həm əla oxuyur, həm də tərbiyə baxımından nümunəvi şagirdlərdir. Bununla yanaşı, bərabərsizlik, köməksizlik və nəzarətsizlik dərəcəsi nə qədər yüksəkdirsə, uşaqların fiziki və psixi sağlamlığı da bir o qədər çox pozulur” [2, s. 158].

Dünya təcrübəsi göstərir ki, uşaqlara lazımi qayğı göstərilməməsi və onlara qarşı aqressiv münasibət son vaxtlar xarici ölkələrdə epidemiya xarakteri alır. Statistik məlumatlara görə, bir sıra ölkədə uşaqlar heç bir qayğı görmür. Bundan başqa, 10-16 yaşlı uşaq və yeniyetmələr arasında bir telefon sorğusu aparılıb. Nəticələr ürəkaçan olmayıb.

Sorğulanan uşaqlardan üçdə biri ailə üzvləri, qonşular, hətta müəllimlər tərəfindən nəinki fiziki, hətta seksual zorakılığa məruz qalıblar. Oksər hallarda belə uşaqlar nə öz yaşıdlarına, nə də məktəbə uyğunlaşa, yaranmış çətinliklərinin öhdəsindən gələ bilmir. Bəzi hallarda belə uşaqlar suiqəsd nəticəsində həyatlarını itirirlər.Müxtəlif yaşlı uşaqlarda da bəzi xəstəliklər əmələ gəlir. Məsələn, yuxu pozğunluğu, beynin inkişaf pozuntuları, depressiya.

Valideynlər sadəcə bir şeyi dərk etməlidirlər: onlar arasında soyuq münasibət təkcə uşaqlara təsir etmir - təcrübə göstərir ki, belə münasibət digər nəsillərə də ötrülür. Ona görə də valideynlərə belə müraciət edilməlidir: əgər siz övladlarınızı və gələcək nəsli sağlam, xoşbəxt görmək istəyirsinizsə, onda bir-birinizlə ümumi dil tapmağa çalışın, bir-birinizə qarşı kompromisə gedin! Belə olmasa, nəticə gözlənilməyən ola bilər.

Azərbaycan Respublikası Prezidenti yanında Qeyri-Hökümət Təşkilatlarına Dövlət Dəstəyi Şurasının maliyyə dəstəyi; "Kimsəsiz Uşaqların Sosial Müdafiəsi” İctimai Birliyinin təşkilatçılığı ilə "Uşaqları məişət zorakılığından qorumaq üçün cəmiyyətin maarifləndirilməsi” adlı tədbir keçirilib. Tədbirdə çıxış edənlər vurğulayıb ki, uşaqlıqda istər fiziki, istərsə də psixoloji zorakılığın təsiri bir ömür boyu qalır.

Belə uşaqlar ailə qurduqda özləri də belə hərəkətləri tətbiq edirlər. Bu da təsadüfi hal deyil. Uşaqlara qarşı zorakılıq onların gələcək həyatlarında problemlər yaradır.

Formasından asılı olmayaraq, zorakılıq uşaq hüquqlarının pozulması deməkdir. İstər Uşaq Hüquqları Konvensiyada, istərsə də beynəlxalq müqavilələrdə uşaqların ləyaqəti, toxunulmazlı̆̆ı və təhlükəsizliyi təmin olunursa, uşaqlara qarşı zorakılıq yenə də yayılmaqdadır. Bu problemin həlli isə Avropanın bütün dövlət başçılarını narahat edən məsələdir.

Uşaq zorakılığına aşağıdakı amillər təsir edir:

1. Emosional sui-istifadə. Bura mənəvi və psixoloji təhqir formaları daxildir. Yəni valideyn ya da onu əvəz edən qəyyum ya hərəkəti, ya da hərəkətsizliyi ilə uşaqlara ciddi emosional, ruhi, davranış pozuntularına səbəb olur.

2. Qayğının olmaması. Bura fiziki, emosional, məktəblə bağlı qayğı daxildir.Fiziki qayğının olmaması qida, getimin, tibbi yardımın olmaması, nəzarətin olmaması, təbiət hadisələrindən qorunmanın olmaması kimi amillərdən ibarətdir. Bundan başqa, fiziki qayğının olmamasına uşaqların atılması da aiddir.Təhsil ilə bağlı qayğının olmamasına birinci növbədə məktəbdən 
yayılmasına gətirib çıxarır. Uşaq sevgi, emosional dəstəyi görməyəndə o, pis vərdişlərə yiyələnir. Məsələn, narkotik vasitələrdən və ya spirtli içkilərdən istifadə edir.

3. Cinsi zorakılıq. Bu uşaqlara qarşı məcburi cinsi münasibətlərdir. Bura yalan, hədə-qorxu, təzyiq, məcbur etmək vasitəsilə yaranan münasibətlərdir. Məqsəd - uşaqlarda cinsi hissiyatın yaranmasına nail olmaqdır. Yaş etibarı ilə onlardan çox böyük olan insanların cinsi zövq almaq üçün uşaqlardan istifadə etmək cinsi zorakılıq deməkdir. Bu, birinci növbədə, uşağın "inamlı münasibətlər hüququnun pozulmasıdır" [4,s. 61]. Cinsi zorakılıq uşaqların mənəviyyatını, demək olar ki, məhv edir. Belə ki, bu növ zorakılıq uşaqların təhsilinə, sağlamlı̆̆ına, hətta ünsiyyət bacarıqlarına mənfi təsir göstərir. Alimlərin apardıqları uzunmüddətli tədqiqatları nəticəsində məlumdur ki, "zorakılığdan zorakılıq törəyir: zorakılığa məruz qalan uşaq gələcəkdə bir valideyn kimi zorakılıq tətbiq etməyə meyilli olacaq".

4. Məktəbdə zorakılıq. Bu günə olan statistika həqiqətən qorxuludur. Hər 10 şagirddən biri təhsil aldığı məktəbdə zorakılığa məruz qalır. On dəhşətlisi odur ki, bu rəqəm durmadan artır və bura müəllim-şagird, şagird-şagirdlər münasibətləri daxildir. Məktəblərdə zorakılıq daha çox Avropa məktəblərində yayılıb. Məsələn, digərlərindən fərqlənən, daha ağıllı, daha iri, nitqində qüsur olan, gülüş, qorxutma qurbanı olaraq digər məktəblilər tərəfindən zorakıklığa məruz qalırlar. Çox vaxt sataşmalar miqrantlara və etnik azlıqlara qarşı yönəlir. Təcavüz edənlər əmindirlər ki, onlara güldən artıq söz deyilməyəcək: Avropa məktəblərinin əksəriyyətində fiziki cəza qadağan olsa da, belə hallar geniş yayılmışdır.

İndiki zamanda vəziyyət bir qədər də dəyişib. İndi çox vaxt xoşagəlməz fotolar internetdə yayılır. Belə hallar uşağa çox böyük ziyan vurur. BMT-nin məlumatına görə, “Avropada qızlar oğlanlarla müqayisədə daha çox zorakılığa məruz qalır və məktəbdə baş verən zorakılığın $80 \% 12$ yaşdan 16 yaşa qədər olan yaş qruplarında baş verir" [1, s. 94].

Məktəb direktorları, müəllimlər, valideynlər güclərini səfərbər etməli və məktəb zorakılığının kökünü kəsməlidirlər. Bu isə hasan iş deyil. Ovvəl düşünülmüşs siyasət planı hazırlanmalı, uşaqlar baş verənləri saxlamamalı, onlara konfedensial şikayət etmək üçün şərait yaranmalıdır. Yaxşı olardı ki, bu problemlə bağlı məktəblərdə qarşılıqlı kömək qrupları yaradılardı ki, uşaqlar arasında maarifləndirmə işləri aparılsın.

5. İnternet və digər kütləvi informasiya vasitələrin təsiri.İnternetin və digər KIV-in uşaqlara nece təsirindən cox danışmaq olar. Müsbət tərəflərindən başqa, çox təəssüf ki, mənfi tərəfləri də var. Son zamanlar bu sahədə vəziyyət o qədər pisləşib ki, internet uşaqları pedofillərin təqiblərinə də məruz qoyur, hətta evdə olarkən. Hələ biz uşaq haqqında internetdə yerləşdirilən qeyri-etik informasiyadan danışmırıq. Belə hallar qəsdən də ola bilər, düşünülmədən də. Amma nəticə hər iki halda eynidir: belə məlumat tez yayılır və qarşısını almaq olmur. Bu da uşaqlara qarşı zorakıklıq əlamətidir.

2006-c1 ildə Avropa Şurasının Nazirlər Komitəsi "uşaqların tyeni informasiya və kommunikasiya mühitində hüquqları haqqında xüsusi tövsiyə qəbul etmişdir” [6, s. 74].

6. Uşaq alveri. Ümumiyyətlə, insan alveri insan hüquqlarının ciddi şəkildə pozulmasıdır. Bildiyimiz kimi, bütün insanlar toxunulmazdır, və bu onların ləyaqətinə və toxunulmazlığına qarşı törədilən bir cinayətdir.

Ürək ağrısı ilə qeyd etməliyik ki, insan alverinin qurbanları məhz uşaqlar olur, yəni 18 yaşına çatmamış uşaq istər öz vətənində, istərsə də xarici ölkədə istismar edilir, gizlədilir, hətta dəyişdirilir və satılır. Bir çox hallarda uşaqları aldadaraq bu çirkin əməllərə qurban edirlər: onlara ya səyahət etmək va da Avropanın tanınmış məktəblərində təhsil almaq təklifi altında ölkədən çıxarıb 
gizlədirlər. Amma yaddan çıxarmayaq ki, bəzi yoxsul valideynlər özləri öz üvladlarını pula satırlar.İnsan alveri kimi zorakılığa məruz qalan uşaqlar belə alçaldıcı münasibətdən özlərini qoruya bilmirlər, çünki belə hüquqdan məhrumdurlar.

Gördüyümüz kimi, "Uşaqlar həyat çiçəkləridir" deyilən adi bir ifadə yalnız qismən doğrudur. Uşaqlar, çox güman ki, həyat ağacındakı çiçəklər deyil, kökləridir, çünki bu gün onların tam inkişafı yaxın gələcəkdə cəmiyyətin simasını müəyyənləşdirir.

Uşaqlara münasibət, onların ehtiyac və maraqlarını tam təmin etmək yalnız sosial tərəqqinin, rifahın, cəmiyyətin insanlığının səviyyəsini deyil, həm də uşaqların qayğısına qalmaq, gələcəyinə etibarlı zəmin hazırlayan dövlətin sosial siyasətinin uzaqgörənliyini göstərir. Bu prinsip Uşaq Hüquqları Konvensiyasında əksini tapmışdır və bu da "uşağın fiziki və əqli cəhətdən yetkin olmaması səbəbindən xüsusi qorunma və qayğıya ehtiyacı olduğu" bildirilmişdir.

Ailədə uşaq zorakılığı problemi müasir cəmiyyətin kəskin sosial problemlərindən biridir. $\mathrm{Bu}$ problemin aktuallı̆̆ göstəriciləri ilə müəyyənləşir.

\section{Biblioqrafiya}

1. Инфантильный синдром. Журнал Американской медицинской ассоциации: [Электронный ресурс]. Режим доступа: https://cont.ws/@sari/843393 (дата обращения: 12.02.2020).

2. Хартман С.О домашнем насилии в США. М., 1993. 257c.

3. Сафонова Т. Насилие над детьми: природа, причины, социальная и правовая зашита. M, 1993, 27 c.

4. Насилие в отношении детей и родительская психопатология // Насилие и защита детей в мире конференции, 1-3 октября, М.: 2017, 369 с.

5. Насилие и его влияние на здоровье. Доклад ВОЗ о ситуации в мире. 2003 г. [Электронный peсурс]. Режим доступа: https://apps.who.int/iris/bitstream/handle/10665/ 42495/5777702252_rus.pdf;jsessionid=DAFDDB7D3152DD8D88D94F15F0018166? sequence $=4$ (дата обращения: 14.02.2020) 
Гасанлы Б.Н.

DOI: 10.25108/2304-1730-1749.iolr.2020.62.78-86

УДК 364.29

\section{Понятие насилия и его виды}

Аннотация: Как мы знаем, важность проблемы детского насилия признается как государством, так и обществом. Например, наличие как государственной, так н негосударственной системы социальных услуг, которая защищает детей, а также благотворительных организаций, оказывающих помощь семьям и детям, еще раз свидетельствует о том, что эта проблема постоянно находится в центре внимания. Рассмотрены психологические, социальные и экономические аспекты насилия. Кроме того, отражены формирующиеся в последние годы виды насилия.

Одним из важных вопросов, которые нашли отражение в статье, является перевод некоторых терминов и их использование в текстах. Как мы знаем, подавляющее большинство теоретических положений в отечественной науке основано на научных исследованиях зарубежных ученых. В процессе перевода определенных категорий на иностранный язык встречается множество недостатков. Во многих странах важность проблемы детского насилия признается как государством, так и обществом в целом. Это подтверждается наличием государственной и негосударственной системы социальных услуг, которая защищает права детей, благотворительных организаций, оказывающих помощь семьям и детям. Кроме того, эта проблема становится все более центральной темой международных и региональных конференций.

Ключевые слова: насилие; эксплуатация; злоупотребление: права ребенка; общество.

\section{Библиография}

1. Инфантильный синдром. Журнал Американской медицинской ассоциации: [Электронный ресурс]. Режим доступа: https:/cont.ws/@sari/843393 (дата обращения: 12.02.2020).

2. Хартман С.О домашнем насилии в США. - М., 1993. - 257 с.

3. Сафонова Т. Насилие над детьми: природа, причины, социальная и правовая зашита. M.: 1993. - 27 c.

4. Насилие в отношении детей и родительская психопатология // Насилие и защита детей в мире конференции, 1-3 октября, - М.: 2017. - 369 с.

5. Насилие и его влияние на здоровье. Доклад ВОЗ о ситуации в мире. 2003 г. [Электронный pecypc]. Режим доступа: https:/apps.who.int/iris/bitstream/handle/10665/ 42495/5777702252_rus.pdf;jsessionid=DAFDDB7D3152DD8D88D94F15F0018166? sequence $=4$ (дата обращения: 14.02.2020)

\footnotetext{
•Гасанлы Бахар Назим кызы - магистрант 2 курса Университета Азербайджан. E-mail: 1994.bh@mail.ru.
} 